\title{
Predicting quality attributes of strawberry packed under modified atmosphere throughout the cold chain
}

\author{
Kompal Joshi \\ Technological University Dublin \\ Brijesh Tiwari \\ Teagasc Food Research Centre \\ P. J. Cullen \\ University of Sydney, Patrick.cullen@sydney.edu.au
}

See next page for additional authors

Follow this and additional works at: https://arrow.tudublin.ie/ehsiart

Part of the Food Science Commons, and the Medicine and Health Sciences Commons

\section{Recommended Citation}

Kompal Joshi, Brijesh Tiwari, Patrick J. Cullen, Jesus M. Frias, Predicting quality attributes of strawberry packed under modified atmosphere throughout the cold chain, Food Packaging and Shelf Life, Volume 21, 2019, 100354, ISSN 2214-2894, DOI: 10.1016/j.fpsl.2019.100354.

This Article is brought to you for free and open access by the ESHI Publications at ARROW@TU Dublin. It has been accepted for inclusion in Articles by an authorized administrator of ARROW@TU Dublin. For more information, please contact arrow.admin@tudublin.ie, aisling.coyne@tudublin.ie,gerard.connolly@tudublin.ie. Funder: Department of Agriculture, Food and Marine (Ireland)

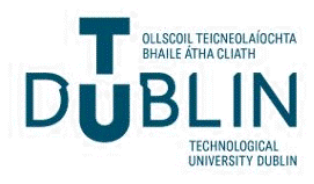


Authors

Kompal Joshi, Brijesh Tiwari, P. J. Cullen, and Jesus Maria Frias

This article is available at ARROW@TU Dublin: https://arrow.tudublin.ie/ehsiart/29 


\title{
Predicting quality attributes of strawberry packed under modified atmosphere
} throughout the cold chain

Kompal Joshi ${ }^{1}$, Brijesh Tiwari ${ }^{2}$, Patrick J Cullen ${ }^{3}$ and Jesus M. Frias ${ }^{1}$

${ }^{1}$ School of Food Science and Environmental Health, Environmental Sustainability and Health Institute, Dublin Institute of Technology, Dublin, Ireland

${ }^{2}$ Department of Food Biosciences, Teagasc Food Research Centre, Ashtown, Dublin 15, Ireland

${ }^{3}$ Department of Chemical and Environmental Engineering, University of Nottingham, United Kingdom

\begin{abstract}
Modified Atmosphere Packaging (MAP) is used commercially to extend the shelf life of strawberries. The attainment of desired gas $\left(\mathrm{O}_{2}, \mathrm{CO}_{2}\right)$ concentrations inside MAP relies on the product respiration and the mass transfer through packaging and will affect the quality. The objective of this work is to build a mathematical model for strawberries to assess the effect of the uncertainties on headspace gas concentration and quality: 1) cold chain related temperature and relative humidity variations and 2) variability associated to product respiration and quality based on literature. Weight loss was more influenced by the cold chain storage conditions (temperature and RH) whereas spoilage had similar influence of cold chain conditions and product parameters. Waste generated in the cold chain was estimated from industrial standard weight loss and spoilage thresholds. A sensitivity analysis of the stochastic MAP model showed the influence of input parameters on the quality pointing to interventions associated to a reduction of the respiration rate (e.g. modification of packaging) and reduction of water transfer (e.g. coating) may prove more successful than other interventions to which the waste generation of this product is not so sensitive to. As a conclusion this work presents a
\end{abstract}


toolbox to interpret cold chain data: 1) develop mathematical models to predict fate of quality 2) simulate cold chain conditions allowing for uncertainty 3) estimate the waste generation kinetics based in quality criteria and thresholds 4) perform a sensitivity analysis to identify most sensitive technological parameters 5) identify interventions that will affect those technological parameters.

Keywords: mathematical modelling; coating, variability; sensitivity analysis; strawberry

\begin{tabular}{|c|c|c|c|}
\hline$a_{w}$ & $\begin{array}{l}\text { Water activity of fresh } \\
\text { produce }\end{array}$ & $\mathrm{P}_{\mathrm{S}}$ & $\begin{array}{l}\text { Saturated vapour pressure } \\
(\mathrm{Pa})\end{array}$ \\
\hline$A_{c}$ & Surface area of produce $\left(\mathrm{m}^{2}\right)$ & $\mathrm{P}_{\mathrm{atm}}$ & $\begin{array}{l}\text { Atmospheric pressure } \\
=101325 \mathrm{~Pa}\end{array}$ \\
\hline$A_{p 1}$ & $\begin{array}{l}\text { Surface area of packaging } \\
\text { film }\left(\mathrm{m}^{2}\right)\left(D_{1} x D_{2}\right)\end{array}$ & $p_{i}$ & $\begin{array}{l}\text { Film permeability to species } \\
\left(\mathrm{i}=\mathrm{O}_{2}, \mathrm{CO}_{2}, \mathrm{H}_{2} \mathrm{O}\right)\left(\mathrm{mL} \mathrm{m} \mathrm{m}^{-}\right. \\
\left.{ }^{2} \mathrm{~h}^{-1} \mathrm{~atm}^{-1}\right)\end{array}$ \\
\hline$A_{p 2}$ & $\begin{array}{l}\text { Surface area of package } \\
\text { bottom }\left(\mathrm{m}^{2}\right)\left(D_{1} x D_{2}\right)\end{array}$ & $p_{\text {iref }}$ & $\begin{array}{l}\text { Reference permeability of } \\
\text { film to } \mathrm{i}=\mathrm{O}_{2}, \mathrm{CO}_{2}, \mathrm{H}_{2} \mathrm{O} \\
\left(\mathrm{mL} \mathrm{m} \mathrm{m}^{-2} \mathrm{~h}^{-1} \mathrm{~atm}^{-1}\right)\end{array}$ \\
\hline$A_{p 3}$ & $\begin{array}{l}\text { Surface area of package walls } \\
\left(\mathrm{m}^{2}\right)\end{array}$ & $\mathrm{Q}_{\mathrm{con}}$ & $\begin{array}{l}\text { Condensation heat released } \\
\text { due to commodity }\left(\mathrm{J} \mathrm{s}^{-1}\right)\end{array}$ \\
\hline$A_{p}$ & $\begin{array}{l}\text { Total surface area of package } \\
\left(\mathrm{m}^{2}\right)\end{array}$ & $Q_{s}$ & Respiration heat $\left(\mathrm{J} \mathrm{h}^{-1}\right)$ \\
\hline$C_{a}$ & Air humid air $\left(\mathrm{J} \mathrm{kg}^{-1} \mathrm{~K}^{-1}\right)$ & $Q_{t r}$ & $\begin{array}{l}\text { Evaporative heat transfer due } \\
\text { to transpiration }\left(\mathrm{J} \mathrm{s}^{-1}\right)\end{array}$ \\
\hline$C_{S}$ & $\begin{array}{l}\text { Specific heat of produce }(\mathrm{J} \\
\left.\mathrm{kg}^{-1} \mathrm{~K}^{-1}\right)\end{array}$ & $Q_{w c o n}$ & $\begin{array}{l}\text { Heat released during } \\
\text { condensation on wallk }\end{array}$ \\
\hline$E_{O_{2}, \mathrm{CO}_{2}}$ & $\begin{array}{l}\text { Activation energy of rate } \\
\text { constant }\left(\mathrm{J} \mathrm{mol}^{-1}\right)\end{array}$ & $r_{\mathrm{CO}_{2}}$ & $\begin{array}{l}\mathrm{CO}_{2} \text { production rate }(\mathrm{mol} \mathrm{kg} \\
\left.{ }^{1} \mathrm{~s}^{-1}\right)\end{array}$ \\
\hline$d_{c}$ & $\begin{array}{l}\text { Equivalent diameter of } \\
\text { produce }(\mathrm{cm})\end{array}$ & $r_{O_{2}}$ & $\begin{array}{l}\mathrm{O}_{2} \text { consumption rate }(\mathrm{mol} \mathrm{kg} \\
\left.{ }^{1} \mathrm{~s}^{-1}\right)\end{array}$ \\
\hline$d_{H}$ & Diameter of perforation (mm) & $R$ & Gas constant $\left(8.314 \mathrm{~J} \mathrm{~mol}^{-1}\right.$ \\
\hline
\end{tabular}




\begin{tabular}{|c|c|c|c|}
\hline & & & $\left.\mathrm{K}^{-1}\right)$ \\
\hline$D_{1} x D_{2} x D_{3}$ & Dimensions of package $(\mathrm{cm})$ & $\operatorname{Rel}_{M R}$ & Relative metabolic rate \\
\hline$D_{i, \text { air }}$ & $\begin{array}{l}\text { Diffusion coefficient of } \mathrm{I}= \\
\mathrm{O}_{2}, \mathrm{CO}_{2}, \mathrm{H}_{2} \mathrm{O} \text { in air }\left(\mathrm{m}^{2} \mathrm{~s}^{-1}\right)\end{array}$ & $R Q$ & Respiratory Quotient \\
\hline$h_{p}$ & 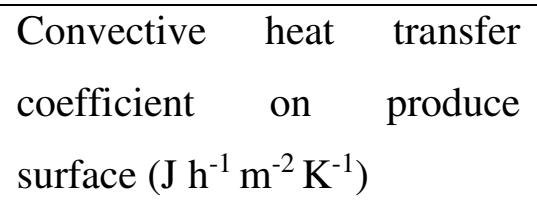 & $R_{h}$ & Radius of perforation (m) \\
\hline$H R$ & Humidity Ratio & $\mathrm{RH}$ & $\begin{array}{l}\text { Relative humidity inside } \\
\text { package }(\%)\end{array}$ \\
\hline$H R_{\text {sat }}$ & $\begin{array}{l}\text { Humidity Ratio of saturated } \\
\text { water vapour }\end{array}$ & $\mathrm{RH}_{\mathrm{O}}$ & $\begin{array}{l}\text { Relative humidity outside } \\
\text { package }(\%)\end{array}$ \\
\hline$K_{a}$ & $\begin{array}{l}\text { Air-film mass transfer } \\
\text { coefficient }\left(\mathrm{kg} \mathrm{m}^{-2} \mathrm{~s}^{-1} \mathrm{~Pa}^{-1}\right)\end{array}$ & $\mathrm{t}$ & Time (s) \\
\hline $\mathrm{K}_{\mathrm{s}}$ & $\begin{array}{l}\text { Skin mass transfer coefficient } \\
\left(\mathrm{kg} \mathrm{m}^{-2} \mathrm{~s}^{-1} \mathrm{~Pa}^{-1}\right)\end{array}$ & $t_{r}$ & Transpiration rate $\left(\mathrm{kg} \mathrm{m}^{-2} \mathrm{~h}^{-1}\right)$ \\
\hline$K_{t}$ & $\begin{array}{l}\text { Transpiration coefficient }(\mathrm{kg} \\
\left.\mathrm{m}^{-2} \mathrm{~s}^{-1} \mathrm{~Pa}^{-1}\right)\end{array}$ & $T_{i}$ & $\begin{array}{l}\text { Temperature inside package } \\
(\mathrm{K})\end{array}$ \\
\hline$K_{\mathrm{mO}_{2}}$ & $\begin{array}{l}\text { Michaelis-Menten constant in } \\
\mathrm{O}_{2} \text { consumption }\left(\% \mathrm{O}_{2}\right)\end{array}$ & $T_{o}$ & $\begin{array}{l}\text { Temperature outside package } \\
(\mathrm{K})\end{array}$ \\
\hline$K_{\mathrm{mCO}_{2}}$ & $\begin{array}{l}\text { Michaelis-Menten constant in } \\
\mathrm{CO}_{2} \text { evolution }\left(\% \mathrm{O}_{2}\right)\end{array}$ & $T_{S}$ & $\begin{array}{l}\text { Temperature of produce } \\
\text { surface }(\mathrm{K})\end{array}$ \\
\hline $\mathrm{Kmc}_{\mathrm{CO}_{2}}$ & $\begin{array}{l}\text { Michealis-Menten constant } \\
\text { for competitive inhibition of } \\
\mathrm{CO}_{2}(\mathrm{kPa})\end{array}$ & $T_{\text {ref }}$ & $\begin{array}{ll}\text { Produce } & \text { reference } \\
\text { temperature }(\mathrm{K}) & \end{array}$ \\
\hline $\mathrm{Km}_{i \mathrm{O}_{2}(f)}$ & $\begin{array}{l}\text { Michealis-Menten constant } \\
\text { for inhibition on the } \\
\text { fermentative metabolism by } \\
\left(\mathrm{i}=\mathrm{O}_{2}, \mathrm{CO}_{2}\right)(\mathrm{kPa})\end{array}$ & $V_{b}$ & Bulk volume of produce $\left(\mathrm{m}^{3}\right)$ \\
\hline $\mathrm{Kmu}_{\mathrm{CO}_{2}}$ & $\begin{array}{l}\text { Michealis-Menten constant } \\
\text { for non-competitive } \\
\text { inhibition of } \mathrm{CO}_{2}(\mathrm{kPa})\end{array}$ & $V_{f}$ & $\begin{array}{l}\text { Free volume in headspace } \\
(\mathrm{mL})\end{array}$ \\
\hline $\mathrm{L}_{\mathrm{f}}$ & $\begin{array}{l}\text { Thickness of packaging film } \\
\text { (m) }\end{array}$ & $\mathrm{V}_{\mathrm{mO}_{2}}$ & $\begin{array}{l}\text { Maximum } \mathrm{O}_{2} \text { consumption } \\
\text { rate }\left(\mathrm{mL} \mathrm{kg} \mathrm{k}^{-1} \mathrm{~h}^{-1}\right)\end{array}$ \\
\hline
\end{tabular}




\begin{tabular}{|c|c|c|c|}
\hline LSODE & $\begin{array}{lr}\text { Livermore } & \text { Solver for } \\
\text { Ordinary } & \text { Differential } \\
\text { Equations } & \end{array}$ & $\mathrm{V}_{\mathrm{mCO}_{2}}$ & $\begin{array}{l}\text { Maximum } \mathrm{CO}_{2} \text { evolution rate } \\
\left(\mathrm{mL} \mathrm{kg}^{-1} \mathrm{~h}^{-1}\right)\end{array}$ \\
\hline $\mathrm{m}_{\mathrm{pr}}$ & $\begin{array}{l}\text { Rate of water permeation } \\
\text { through film }\left(\mathrm{kg} \mathrm{sec}^{-1}\right)\end{array}$ & VPD & Vapour pressure deficit $(\mathrm{Pa})$ \\
\hline MAP & $\begin{array}{l}\text { Modified Atmosphere } \\
\text { Packaging }\end{array}$ & $\mathrm{W}_{\mathrm{a}}$ & Weight of dry air $(\mathrm{kg})$ \\
\hline $\mathrm{M}_{\text {con }}$ & $\begin{array}{l}\text { Condensation rate on } \\
\text { commodity }\left(\mathrm{kg} \mathrm{s}^{-1}\right)\end{array}$ & $W_{l}$ & Weight loss \\
\hline $\mathrm{M}_{\mathrm{wcon}}$ & $\begin{array}{l}\text { Condensation rate on package } \\
\text { walls }\left(\mathrm{kg} \mathrm{s}^{-1}\right)\end{array}$ & $\mathrm{W}_{\mathrm{s}}$ & Weight of produce $(\mathrm{kg})$ \\
\hline $\mathrm{M}_{\mathrm{i}}$ & $\begin{array}{l}\text { Molar mass of species }(\mathrm{i}= \\
\left.\mathrm{O}_{2}, \mathrm{CO}_{2}, \mathrm{H}_{2} \mathrm{O}, \mathrm{C}\right)\left(\mathrm{kg} \mathrm{mol}^{-1}\right)\end{array}$ & {$\left[\mathrm{CO}_{2}\right]_{\mathrm{i}, \mathrm{o}}$} & $\begin{array}{l}\mathrm{CO}_{2} \text { concentration (i=inside, } \\
\text { outside) package }(\%)\end{array}$ \\
\hline $\mathrm{N}$ & Spoilage & {$\left[\mathrm{O}_{2}\right]_{\mathrm{i}, \mathrm{o}}$} & $\begin{array}{l}\mathrm{O}_{2} \text { concentration (i=inside, } \\
\text { outside) package }(\%)\end{array}$ \\
\hline $\mathrm{N}_{\mathrm{o}}$ & Initial spoilage of batch & Greeks & \\
\hline $\mathrm{N}_{\max }$ & Maximum spoilage & $\alpha$ & Heat conversion factor \\
\hline $\mathrm{N}_{\mathrm{h}}$ & Number of perforations & $\epsilon$ & Porosity \\
\hline $\mathrm{P}_{\mathrm{i}}$ & $\begin{array}{l}\text { Partial vapour pressure inside } \\
\text { package }(\mathrm{Pa})\end{array}$ & $\lambda$ & $\begin{array}{l}\text { Latent heat of vaporization (J } \\
\left.\mathrm{kg}^{-1}\right)\end{array}$ \\
\hline $\mathrm{P}_{\mathrm{c}}$ & $\begin{array}{l}\text { Partial vapour pressure at } \\
\text { commodity surface }(\mathrm{Pa})\end{array}$ & $\rho_{b}$ & $\begin{array}{l}\text { Bulk density of produce }(\mathrm{kg} \\
\left.\mathrm{m}^{-3}\right)\end{array}$ \\
\hline $\mathrm{P}_{\mathrm{o}}$ & $\begin{array}{l}\text { Partial vapour pressure } \\
\text { outside package }(\mathrm{Pa})\end{array}$ & & \\
\hline
\end{tabular}

\section{Introduction}

Strawberries are highly perishable in nature with high metabolic rate and thus have short shelf life. The major limiting factor of the quality of strawberries is spoilage due to Botrytis infection. The tissue of strawberry deteriorates through natural senescence during the food distribution chain and Botrytis develops due to tissue softening as a result of over ripening (Hertog et al., 1999). Other limiting factors to strawberry shelf 
life are appearance, texture and taste, which are affected by decay and weight loss during the supply chain. The most effective intervention to extend the shelf life is to use low temperature storage (Sanz et al., 2000). Packaging is another important technique to extend the shelf life of perishable fruit to facilitate a longer transportation distribution (Caner et al., 2008). The storage quality can be further improved by using modified atmosphere packaging (MAP) and altering the concentration of gases surrounding the fresh strawberry (Geysen et al., 2005; Zhang et al., 2003).

MAP has been used to increase and preserve the shelf-life of produce, while also responding to the emerging consumer demand for convenience and quality. The design of optimal MAP for a specific produce depends on the characteristics of the produce, permeability of the packaging film and dependence on external factors such as temperature and relative humidity (Zagory and Kader, 1988). Apart from extending the shelf life of strawberries it maintains the quality characteristics firmness, prevents weight loss and microbial spoilage (Caner et al., 2008; Larsen and Watkins, 1995; Pelayo et al., 2003).

\section{Sources of uncertainty in postharvest distribution of strawberries}

Managing uniform quality of produce is a tedious task due to the many sources of variability, inherent biological variation and fluctuation occuring in storage conditions (Duret et al., 2015). Postharvest management aims at controlling the variation as much as possible by sorting and grading the product at different stages of the postharvest chain (Hertog et al., 2009a). Identifying and quantifying different sources of variance in the experimental data and assigning uncertainties to the parameter values and error provides better interpretation of the postharvest behaviour (Aguirre, 2008; Hertog et al., 2007a). Biological variation has been previously studied by including this variation in the quality change model, estimating the initial variation ("harvest age") and using it to 
assess the effect throughout the postharvest chain (Hertog et al., 2009b). Over the last decade models explaining biological variation in fresh produce have been developed (Duret et al., 2015; Gwanpua et al., 2014; Hertog et al., 2007b, 2004).

In a MAP gas exchange kinetic model the uncertainty can also be estimated at the respiration models of strawberries. Michaelis-Menten inhibition constants for $\mathrm{O}_{2}$ consumption $\left(\mathrm{Km}_{\mathrm{O}_{2}}\right)$ and fermentative $\mathrm{CO}_{2}$ production $\left(\mathrm{Kmc}_{\mathrm{O}_{2}(f)}\right)$, the reference rate constant of maximum oxygen consumption $\left(\mathrm{Vm}_{\mathrm{O}_{2}}\right)$ and maximum carbon dioxide production $\left(\mathrm{Vm}_{\mathrm{CO}_{2}(f)}\right)$ and the activation energy rate that have been experimentally assessed will have an associated uncertainty, conventionally in the form of a standard error (Hertog et al., 1999).

When describing the kinetics of weight loss in a packaged produce, the fruit skin mass transfer coefficient $\left(\mathrm{K}_{\mathrm{s}}\right)$ is one of the main source of product variation due to the structural variation in the skin of individual fresh produce along with the initial spoilage of the batch $\left(\mathrm{N}_{0}\right)$ (Hertog et al., 1999). The statistical values of these parameters are presented in Table 2 .

The objective of this study is to predict the quality of strawberry in the supply cold chain. The assessment of the effect of cold chain variability and product variability on the quality of strawberry will help estimate the waste generated. A sensitivity analysis was carried out to quantify the effect of different parameters and design an intervention that will reduce losses in the supply chain.

\section{Materials and Methods}

\subsection{Model hypothesis}

1. $\mathrm{CO}_{2}$ production is a combination of oxidative and fermentative production, the oxidative consumption is proportional to the $\mathrm{O}_{2}$ evolution and the fermentative production follows the Michaelis-Menten equations. 
2. The temperature of the surface of commodity $\left(\mathrm{T}_{\mathrm{S}}\right)$ is equal to the temperature of air surrounding the commodity $\left(\mathrm{T}_{\mathrm{i}}\right)$.

3. The surface of the commodity is assumed to be perfectly saturated condition.

4. The metabolic energy released by produce, large part of it (80-100\%) is dissipated as heat.

5. Condensation of water may occur in the product or the package when the free volume air relative humidity reaches $100 \%$ using a saturated surface model.

6. The quality of strawberry is described as weight loss due to transpiration and by Botrytis spoilage as modelled by (Hertog et al., 1999).

\subsection{Mathematical Model development}

The mathematical model takes into account the heat and mass transfer balances due to the metabolic behaviour of strawberry and the transport phenomenon across package. The assumptions used in the mathematical model and sub model to describe respirationtranspiration of strawberry and gas transport across package (Table 1). The influence of these on the quality of strawberry during distribution chain is estimated.

\subsubsection{Transpiration}

Transpiration is caused due to vapour pressure deficit VPD $(\mathrm{Pa})$ between the produce surface and the surrounding atmosphere (Xanthopoulos et al., 2012). VPD is the function of difference in the amount of moisture in air and the amount of moisture air can hold when it is saturated (Becker et al., 1996).

$V P D=\left(a_{w}-R H\right) p_{s}$

It is assumed that water activity of strawberry is ( $\left.a_{w} \sim 0.99\right)$. 
Saturated water vapour pressure at the surface of commodity can be calculated using following equation (Rennie and Tavoularis, 2009) based on saturated water vapour pressure data from ASHRAE (1997).

$p_{s}=0.041081186 T_{s}^{3}-32.43188 T_{s}^{2}+8567.5269 T_{s}-757070.1$

Transpiration occurs when water vapour pressure at the surface of commodity exceeds the water vapour pressure of the headspace of package (Becker et al., 1996; Xanthopoulos et al., 2012).

$m_{w}=V P D \times K_{t}$

Transpiration rate $\left(\mathrm{kg} \mathrm{m}^{-2} \mathrm{~h}^{-1}\right)$ is product of water vapour flux $\left(m_{w}\right)$ and the surface area of the commodity $\left(A_{c}\right)$

$t_{r}=m_{w} A_{c}$

4

$K_{t}=\frac{1}{\left(\frac{1}{K_{S}}+\frac{1}{K_{a}}\right)}$

Here, $K_{t}$ is transpiration coefficient $\left(\mathrm{kg} \mathrm{m}^{-2} \mathrm{~s}^{-1} \mathrm{~Pa}^{-1}\right)$ which is constant for the same commodity, $K_{S}\left(\mathrm{~kg} \mathrm{~m}^{-2} \mathrm{~s}^{-1} \mathrm{~Pa}^{-1}\right)$ is skin mass transfer coefficient obtained from literature, $K_{a}\left(\mathrm{~kg} \mathrm{~m}^{-2} \mathrm{~s}^{-1} \mathrm{~Pa}^{-1}\right)$ is air film mass transfer coefficient calculated using the SherwoodReynolds-Schmidt correlations (Becker et al., 1996) .

$S h=\frac{K_{a} d_{c}}{D_{H_{2} O} O \text { air }}$ 6

For convective mass transfer from commodity spherical in shape, (Becker et al., 1996) recommended Sherwood-Reynolds-Schmidt correlation of the following form to be used.

$S h=2.0+0.552 R e^{0.53} S c^{0.33}=\frac{K_{a}^{\prime} d_{c} R T_{S}}{D_{\mathrm{H}_{2} \mathrm{O} \text {,air } M_{\mathrm{H}_{2} \mathrm{O}} \mathrm{O}}}$ 
It is assumed, there is negligible flow around the commodity $(R e \approx 0)$. Therefore, air film mass transfer coefficient can be calculated as:

$K_{a}=2 \times \frac{D_{\mathrm{H}_{2} \mathrm{O}-\text { air }} M_{\mathrm{H}_{2} \mathrm{O}}}{d_{c} R T_{s}}$

8

\section{Transpiration Heat}

The process of transpiration requires energy for evaporation of moisture from surface of produce, this process cools down the commodity. Evaporative heat transfer rate $\left(Q_{t r}\right)$ is a product of latent heat of vaporization $(\lambda)$ and transpiration rate $\left(t_{r}\right)$.

$$
Q_{t r}=\lambda t_{r}
$$

\subsubsection{Relative humidity in headspace}

The concentration of water vapour inside the package is dependent on the rate of water vapour transfer from the moisture sources to moisture sinks within the package. The main moisture sources in the package is water transpired from the surface of fresh produce $\left(t_{r}\right)$ and the main source of moisture sink is permeation of water vapour through the film $\left(\mathrm{m}_{\mathrm{pr}}\right)$ (Becker et al., 1996).

The amount of water vapour in the headspace is calculated using humidity ratio which is the ratio of mass of water vapour in headspace to mass of dry air in the headspace of package $(\mathrm{kg} / \mathrm{kg})$.

$\frac{d H R}{d t}=\frac{t_{r}-m_{p r}}{W_{a}}$

Relative humidity is calculated as ratio of humidity ratio inside the package $(H R)$ to the humidity ratio of saturated water vapour $\left(H R_{s a t}\right)$ (Jalali et al., 2017; Song et al., 2002).

$H R_{\text {sat }}=\frac{0.62198 P_{S}}{\left(P_{a t m}-P_{S}\right)}$ 
$R H=\frac{H R}{H R_{\text {sat }}}$

\subsubsection{Condensation}

In perforation mediated packaging condensation rate is seldom modelled in MAP, due to near saturation conditions and non-uniform or fluctuating temperature within the package, condensation can occur on the commodity surface or inside of package film and walls. It is assumed that the water vapour condensed on the surface of commodity does not penetrate the skin of fresh produce. For condensation to take place the partial pressure of water vapour should be greater than the saturated water vapour pressure (Jalali et al., 2017; Joshi et al., 2018; Rennie and Tavoularis, 2009).

$M_{\text {con }}=\left\{\begin{array}{cl}K_{a}\left(P_{\mathrm{H}_{2} \mathrm{O}-} P_{c}\right) \delta A_{c}, & \text { if }\left(P_{\mathrm{H}_{2} \mathrm{O}}>P_{S}\right) \\ 0 & \text { otherwise }\end{array}\right.$

The corresponding rate of release of heat due to condensation on the surface of commodity is $Q_{\text {con }}$ calculated as:

$Q_{\text {con }}=\lambda M_{\text {con }}$ 14

The rate of condensation on package wall $\left(\mathrm{M}_{\mathrm{wcon}}\right)$ is calculated similarly using air film mass transfer coefficient $\left(\mathrm{K}_{\mathrm{a}}\right)$.

$M_{\text {wcon }}=\left\{\begin{array}{cl}K_{a}\left(P_{\mathrm{H}_{2} \mathrm{O}-} P_{S}\right) \delta A_{w}, & \text { if }\left(P_{\mathrm{H}_{2} \mathrm{O}}>P_{s}\right) \\ 0 & \text { otherwise }\end{array}\right.$

The heat released during condensation $\left(\mathrm{Q}_{\mathrm{wcon}}\right)$ heats up gases in atmosphere near wall.

$Q_{w c o n}=\frac{\lambda M_{w c o n}}{A_{w}}$

\subsubsection{Quality}

The quality of fresh produce is determined by the overall characteristics (appearance, texture, flavour and nutritive value) of fresh produce (ElMasry et al., 2007). The perception of quality is highly subjective and depends on consumer and number of 
qualitative factors. Quality of fresh produce in general is often described using a chemical kinetic model (Merts, 1996). The main attributes of quality in strawberries is weight loss and spoilage.

\subsubsection{Weight loss}

The amount of water vapour transpired from the surface of fruit $\left(t_{r}\right)$ and carbon loss due to respiration accounts for the weight loss.

$\frac{d W_{l}}{d t}=t_{r}+M_{c} r_{C O_{2}} W_{s}$

\subsubsection{Spoilage}

The inhibition of spoilage in strawberry in modified atmosphere is assumed to be the result from inhibitory effect of gas composition on gas exchange in strawberry. When the gas exchange is inhibited the overall metabolic rate and the ripening rate will be inhibited resulting in a slower spoilage rate (Hertog et al., 1999). (Tijskens and Polderdijk, 1996) used relative metabolic rate (eq 18), which represents a ratio of the actual respiration rate under any gas conditions to the respiration rate under normal air conditions $\left(21 \% \mathrm{O}_{2}, 0.03 \% \mathrm{CO}_{2}\right)$ at the same temperature. In the case of strawberries fermentative activities are taken into account in the respiration model therefore the gas exchange is expressed in terms of $\mathrm{CO}_{2}$ production.

$\operatorname{Rel}_{M R}=\frac{r_{\mathrm{CO}_{2(f)}\left(\left[\mathrm{O}_{2}\right],\left[\mathrm{CO}_{2}\right],\left[\mathrm{H}_{2} \mathrm{O}\right], T_{S}\right)}}{r_{\mathrm{CO}_{2}}\left(21 \% \mathrm{O}_{2}, 0.03 \% \mathrm{CO}_{2}, T_{S}\right)}$

The spoilage of strawberry due to Botrytis, in terms of percentage of strawberry affected can be described by the following ordinary differential.

$\frac{d N}{d t}=\operatorname{Rel}_{M R} \times k_{s} \times N \times\left(\frac{N_{\max }-N}{N_{\max }}\right)$, initiate at $N_{0}$ 
Where $\mathrm{N}_{\max }$ is maximum spoilage $(100 \%), \mathrm{k}_{\mathrm{s}}$ is the spoilage rate constant which depends on the temperature according to Arrhenius equation. The value of activation energy associated with the spoilage rate constant is mentioned in table 2.

\subsection{Numerical Simulations of the ODE system}

To estimate the effect of input parameter uncertainty on the prediction of concentration of gases and effect on quality during the cold chain distribution, Monte Carlo simulations were performed to simulate three scenarios:

1) A distribution scenario where temperature and relative humidity are varying with the cold chain data, as described in Joshi et al. (2018).

2) A distribution scenario with an ideal cold storage temperature $\left(4^{\circ} \mathrm{C}\right)$. and relative humidity (80\%) and with variable product properties, as specified in Table 6.2.

3) A distribution scenario considering the joint uncertainties of 1) and 2).

The value of product parameters used in the model are in table 2. The ordinary differential model was solved using the deSolve library (Soetaert et al., 2010) using the lsoda solver on R 3.4.3 (R Development Core Team, 2008). All the plots were produced using the ggplot2 library (Wickham, 2009). Sensitivity analysis using a main and first order interactive effects model excluding time were analysed using a Lowry plot (McNally et al., 2011).

\subsection{Uncertainty assessment}

\subsubsection{Assessment of the impact of cold chain on quality in cold chain}

A simulation scenario considering average product characteristics without variation and a variable cold chain temperature and relative humidity profile was used to assess the importance of different transport and retail conditions. This simulation scenario used cold chains of 3 and 6 days of temperature and relative humidity export profiles from (Joshi et al. 2018). The mathematical model was simulated against these 
cold chain profiles to study the effect of cold chain uncertainty on the quality of strawberry results are presented in following sections

\subsubsection{Assessment of product variability on waste production}

A simulation scenario considering full product variability and constant storage conditions was used to assess the relative effect of different product variability sources. The storage conditions tested involved:

1) An ideal storage temperature of $4^{0} \mathrm{C}$ and relative humidity $80 \%$.

2) An abuse cold chain composed of the following steps: 2 hours of packaging at $8^{0} \mathrm{C}$ followed by retail storage for up to 1.5 day at $4^{0} \mathrm{C}$, transportation at $8^{0} \mathrm{C}$ for 1 day and retail shop storage at $4^{0} \mathrm{C}$ for 3 days.

The product parameters responsible for the variability are presented in Table 2 .

The results in Section 2.6.2 shows the uncertainty due to the product parameters uncertainty on the quality parameters of strawberry.

To further investigate the effect of individual product parameter, a sensitivity analysis was performed using a main and first order interactive effects model excluding time. The results are presented using a Lowry plot (McNally et al., 2011)

\subsubsection{Combined assessment of product and cold chain uncertainty effect on waste}

Section 2.6.3 presents the combined assessment of cold chain uncertainty and product uncertainty. This study contributes to the identification of the relative influence of different parameter uncertainties and the interventions that can be designed to maintain the quality and reduce the waste in supply chain. A sensitivity analysis was also carried out to access the effect of individual parameters on the produce quality, as explained in the next section.

\section{Sensitivity analysis}


The input parameters of the sensitivity analysis are shown in Table 2 . The results of the sensitivity analysis were presented using a Lowry plot (McNally et al., 2011). The total effect of the main parameters are given in black and any first order interactions with other parameters is represented in grey s a proportion of the variance. The ribbon represents the variance due to parameter interactions, while the cumulative sum of the main effects and the sum of the total effects is indicated by the lower line and upper line, respectively.

\section{Estimation of waste generation}

The losses observed in the strawberry cold supply chain are ascribed to weight loss and spoilage. The simulation results of product variability were used to calculate the waste generated based on the industrial thresholds. Conditional density plots were used to illustrate the waste produced in the strawberry supply chain.

\subsection{Validation}

Strawberry $(150 \mathrm{~g}, 3-5 \mathrm{~cm}$ diameter) were purchased from local wholesale fruit market Dublin, Ireland and packaged in an industry standard perforated polypropylene LDPE film (4 perforations) and were stored in either ideal conditions $\left(4^{0} \mathrm{C}\right)$ or abuse condition $\left(1 / 2\right.$ day in packaging facility at $8{ }^{\circ} \mathrm{C}$ followed by transportation at $4{ }^{\circ} \mathrm{C}$ up to 2 days, followed by retail storage including $4 \mathrm{~h}$ at $20^{\circ} \mathrm{C}$, followed by 2 days at $8{ }^{\circ} \mathrm{C}$, and finalised by retail shop $4 \mathrm{~h}$ at $20^{\circ} \mathrm{C} 2$ days at $8^{\circ} \mathrm{C}$ ) for a period of 10 days.

A chitosan solution $(1.5 \%)$ was prepared by dissolving chitosan (Sigma-Aldrich Ltd., UK, medium molecular weight, $75-85 \%$ deacetylated) in distilled water containing $1 \%$ glacial acetic acid using a magnetic stirrer. After complete dissolution $0.2 \%$ Tween 80 (Sigma-Aldrich Ltd., UK) was added to the solution. The $\mathrm{pH}$ of the solution was adjusted to 5.2 with $1 \mathrm{~N} \mathrm{NaOH}$ (Sigma-Aldrich Ltd., UK) (Petriccione et al., 2015). A second sample of the same batch of strawberries was immersed in chitosan solution for 
60s then allowed to dry for 1 hour in air dryer at room temperature and stored in the same conditions as above.

Strawberries were visually examined on regular intervals during storage period. The fruits showed surface mycelia growth or bacterial lesions were considered decay. Results were expressed as percentage of spoiled fruits. Weight loss was expressed as percentage loss of initial weight (Han et al., 2004).

\subsection{Results and discussions}

\subsubsection{Cold chain variability assessment}

The mathematical model presented in section 2 was used to simulate the effect of cold chain variation on the changes in the concentration of gases in the headspace and quality of strawberry. The governing ODE equations (24 and 25) in table 1 were used to obtain the concentration of carbon dioxide and oxygen package's headspace. The results presented in Fig 1 were simulated in contrast with the export cold chain. The creation and maintenance of optimal atmosphere inside the modified atmosphere package depends on the product's respiration rate and on the permeability of the films, both of which are dependent on temperature. At very low oxygen concentration $(<2 \%)$, anaerobic respiration is initiated in the tissue, which shortens the shelf life. However, the results obtained from the simulations showed there was no anaerobic condition was observed in the package.

Temperature fluctuations and their effect on the atmosphere inside the package had a major effect on strawberry quality. The spoilage increased with higher temperatures, however the effect of MA was also evident. A linear effect of $\mathrm{CO}_{2}$ concentration on spoilage was. At $0 \% \mathrm{CO}_{2}, 1.72 \%$ spoilage was observed, versus to $0.87 \%$ spoilage at $18 \% \mathrm{CO}_{2}$ (Kader, 1986). At higher $\mathrm{CO}_{2}$ concentration (20-80\%), a clear inhibition occurred. At these extremely high levels of $\mathrm{CO}_{2}$, fungal growth is indeed inhibited in 
strawberries (Ke et al., 1991). The amount of water vapour in the headspace of the package was estimated using Fick's diffusion and psychometric equations to calculate the relative humidity inside the package. The results showed that the package is saturated $(\mathrm{RH}=100 \%)$ during storage Fishman et al. (1996) obtained similar results for MAP of mango, and Song et al. (2002) obtained similar experimental and predicted results of relative humidity saturating rapidly during storage.

Weight loss as a result of transpiration and carbon loss due to respiration was directly dependent on temperature (Fig 1 (c)). Sanz et al. (2000) reported weight loss of 3.53\% in control packages and $0.9 \%$ in micro-perforated packages towards the end of storage (7 days). The barrier in the movement of water vapour through the film and perforations leads to less weight loss. The spike in spoilage (>5\%) after 2 days of storage is attributed to the result of abusive temperature profile. A linear effect of $\mathrm{CO}_{2}$ concentration was observed on spoilage: $1.72 \%$ spoilage at $0 \% \mathrm{CO}_{2}$ and $0.87 \%$ spoilage at $18 \% \mathrm{CO}_{2}$ (Kader, 1986).

\subsubsection{Product variability assessment}

Knowledge of the impact of biological variation on quality within a batch is very important to assure a uniform quality in the cold chain. could the variability assessment aids the prediction of factors responsible for quality deterioration during storage. The model developed in this study can help find the effect of variability on the quality parameters. (Hertog et al., 1999). The results obtained are estimates of the values expected due to the variability in the product parameters. The dimensions used are shown in Table 2. Fig 3 shows the propagation of product parameters on the quality characteristics of strawberry at different storage temperatures $\left(4,8\right.$ and $\left.20^{\circ} \mathrm{C}\right)$. It is evident from the figure that the variation is directly dependant on temperature, where the higher temperatures have higher associated variation. 
$\mathrm{Vm}_{\mathrm{O}_{2} \text {, ref }}$ and $\mathrm{Vm}_{\mathrm{CO}_{2}(\mathrm{f}) \text { ref }}$ are the respiration rate parameters which are directly dependant on temperature. The increase in temperature resulted in increase in the respiration rate. Geysen et al. (2005) reported the effect of temperature on the activation energy of maximum $\mathrm{O} 2$ consumption. The weight loss of strawberry constantly increased with time and higher weight loss was observed at higher temperatures. Strawberries have no protective skin which leads to higher weight loss due to transpiration The uncertainty associated with weight loss due to the product parameters was lower. As the storage temperature increased, the variability also increased, as evident from Fig 3c. The weight loss was lower than $0.5 \%$ at $4^{\circ} \mathrm{C}$ in 10 days, whereas at $20^{\circ} \mathrm{C}$ the weight loss reached $2.7 \%$. Spoilage increased with storage temperature, as shown in Fig 3d. Spoilage was lower than $15 \%$ in 10 days storage, around $37 \%$ at $8^{\circ} \mathrm{C}$, $100 \%$ spoilage at $20^{\circ} \mathrm{C}$ in 6 days. The effect of $\mathrm{CO}_{2}$ on spoilage could be explained by the effect of $\mathrm{CO}_{2}$ on the respiration rate. Hertog and co-authors (1999) showed that Botrytis inoculated fruits displayed an inhibitory effect of $\mathrm{CO}_{2}$ on spoilage levels below $20 \%$, which was strongly batch dependant.

\subsubsection{Comparing the effect of variability on strawberry quality}

The uncertainty associated with cold chain variability (temperature and relative humidity) and the variation associated with biological product parameters were compared by plotting kernel density plots for each food chain distribution day and for each of the scenarios. Fig 3 (a) and (b) show how the concentration of gases in the package's headspace is dependent both on cold chain and product variability. The second peak observed in the figure is the result of abusive storage temperature $\left(>10^{\circ} \mathrm{C}\right)$. Variations at the $4^{\text {th }}$ day of distribution in $\mathrm{CO}_{2}$ and $\mathrm{O}_{2}$ concentrations seems to be 
largely cold chain dependent, however by day 6 the cold chain variation has reduced below the variation of the product.

The weight loss showed dependence on the cold chain factors and storage temperature and relative humidity. Strawberries stored at $1{ }^{\circ} \mathrm{C}$ showed less than $1 \%$ weight loss in 8 days, versus $8 \%$ at $20^{\circ} \mathrm{C}$ in 4 days, which exceeds the acceptable limit (Nunes et al., 1998). The spoilage rate (Figure 5.4d) was most influenced by the cold chain factors at the start of storage, but product uncertainty had a more prominent impact later during storage. Strawberries have been found to be colonised by the fungus $B$. cinerea before packaging, with the fungal infection increasing with storage time and inadequate storage conditions (Almenar et al., 2007). The initial spoilage $\left(\mathrm{N}_{0}\right)$ is a value representing initial ripening stage or sensitivity of strawberry to botrytis infection (Hertog et al., 1999). From Fig 3c and Fig 3d it is evident that the cold chain conditions (temperature and relative humidity) need to be controlled in order to minimise the product's weight loss. Nevertheless, in the case of spoilage the product parameters are the main cause of variability that need to be controlled to extend the shelf life.

\subsubsection{Sensitivity Analysis}

Sensitivity analysis was performed to study the results of variation and how it could be apportioned qualitatively and quantitatively to different sources of variation in the model input (Kader and Saltveit, 2003). The result of the sensitivity analysis (SA) on the weight loss of packed strawberry is presented in Fig 4 (a). The most important parameters contributing to the $90 \%$ of the variability were a combination of respiration rate parameters $\left(R Q_{o x}, V m_{O_{2}, r e f}, K_{m O_{2}}\right)$, skin mass transfer coefficient $\left(\mathrm{K}_{\mathrm{s}}\right)$ and the activation energies associated with $\left(\mathrm{E}_{\mathrm{aVmO}_{2}}, \mathrm{E}_{\mathrm{aVm}_{\mathrm{CO}_{2}}(\mathrm{f})}\right)$. Main effects interactive effects between the product parameters had an important impact on variability. This 
result suggests that controlling the respiration rate of the fresh produce and reducing the mass transfer through their skin can help reduce losses during the supply chain.

\section{Identification of an effective intervention}

The sensitivity analysis of strawberry spoilage indicates that the most important parameters contributing to $90 \%$ of the variability are initial spoilage and spoilage rate constant $\left(\mathrm{k}_{\mathrm{s}, \mathrm{ref}}\right)$. Thus, the waste due to spoilage can be reduced by ensuring a good initial quality of strawberry and by controlling the spoilage rate during the supply chain. The product parameters contributing to the concentration of $\mathrm{CO}_{2}$ in the package's headspace were $V m_{\mathrm{O}_{2}, \text { ref }}, R Q o x$ and $E_{V m_{\mathrm{O}_{2}, \text { ref }}}$. As these parameters contributed to $90 \%$ of the variability, a waste reduction would be achieved by controlling them.

\subsubsection{Validation experiment}

The input model parameters from Table 2 and 3 are used to compare the experimental and predicted results presented in the Fig 6. The experimental data comprises strawberry stored at ideal temperature $\left(4^{\circ} \mathrm{C}\right)$ and abusive temperatures $\left(4,20,8^{\circ} \mathrm{C}\right)$ for 10 days, in order to simulate real life supply chain conditions. Weight loss, colour, firmness and spoilage were measured at 1, 3, 5, 7 and 10 days. The grey ribbon represents the uncertainty margins of $5 \%$ and $95 \%$ percentiles ascribed to variability.

The results for weight loss showed that the variability associated with the product parameter is not high (Fig 5.3c). Cold chain parameters are responsible for the weight loss variability during the distribution chain of strawberry. Spoilage was highly variable and directly dependent on storage temperature (Fig. 5.3d). The experimental results fall within the uncertainty grey ribbon showing a good agreement with the prediction. 


\subsubsection{Waste generation estimation during the supply chain}

Fig 6 shows the total waste estimation throughout the strawberry supply chain, as a combination of waste due to weight loss and spoilage. Threshold values were used to calculate the waste - weight loss $\geq 5 \%$, when fruits start to shrivel and become unmarketable), and 5\% spoilage. Significant amounts of out-of-specification product yielding to waste appear from day 2 of distribution; by the end of day 3 , approximately $10 \%$ of all product would be potentially unsuitable for consumption, leading to waste generation.

\subsection{Conclusions}

A mathematical model was developed to predict the concentration of gases $\left(\mathrm{O}_{2}, \mathrm{CO}_{2}\right)$ and water vapour in the packaging headspace. The model takes into account the heat and mass transfer processes occurring in MAP, such as respiration, transpiration condensation and transport of gases through the permeable film. The kinetic behaviour of fresh produce was modelled with respect to the cold chain conditions and product parameters. The effect of cold chain variability and product variability on the quality of fresh produce was assessed. Weight loss was shown to be influenced by the cold chain factors. In contrast, spoilage is initially impacted by the cold chain factors, but product variability becomes prominent towards the end of storage. The results of the sensitivity analysis showed that control of the respiration rate and skin mass transfer would help reduce the waste produced the during supply chain. The model validation showed that the model is a good fit to the experimental data.

\section{Acknowledgement}

Funding for this research was provided by the Irish Government under the National Development Plan 2007-2013, through the Food Institutional Research Measure, administered by the Department of Agriculture, Food and Marine. 


\section{Bibliography}

Aguirre, L., 2008. Combination of natural variability estimation with real time measurement for mushroom shelf life assessment. Dublin Dublin Inst. Technol.

Almenar, E., Del-Valle, V., Hernández-Muñoz, P., Lagarón, J.M., Catalá, R., Gavara, R., 2007. Equilibrium modified atmosphere packaging of wild strawberries. J. Sci. Food Agric. 87, 1931-1939.

ASHRAE, R.H., 2006. SI ed. Am. Soc. Heating, Refrig. Air-Conditioning Eng. Atlanta, GA.

Becker, B.R., Misra, A., Fricke, B.A., 1996. Bulk Refrigeration of Fruits and Vegetables Part I: Theoretical Considerations of Heat and Mass Transfer. HVAC\&R Res. 2, 122-134. https://doi.org/10.1080/10789669.1996.10391338

Bird, R.B., 2002. Transport phenomena. Appl. Mech. Rev. 55, R1-R4.

Burton, W.G., 1982. Post-harvest physiology of food crops. Longman Group Ltd.

Caner, C., Aday, M.S., Demir, M., 2008. Extending the quality of fresh strawberries by equilibrium modified atmosphere packaging. Eur. Food Res. Technol. 227, 15751583.

Duret, S., Gwanpua, S.G., Hoang, H.-M., Guillier, L., Flick, D., Laguerre, O., Verlinden, B.E., De Roeck, A., Nicolai, B.M., Geeraerd, A., 2015. Identification of the significant factors in food quality using global sensitivity analysis and the accept-and-reject algorithm. Part III: Application to the apple cold chain. J. Food Eng. 148, 66-73. https://doi.org/http://dx.doi.org/10.1016/j.jfoodeng.2014.09.039

ElMasry, G., Wang, N., ElSayed, A., Ngadi, M., 2007. Hyperspectral imaging for nondestructive determination of some quality attributes for strawberry. J. Food Eng. 81, 98-107. https://doi.org/10.1016/j.jfoodeng.2006.10.016

Fishman, S., Rodov, V., Ben-Yehoshua, S., 1996. Mathematical Model for Perforation 
Effect on Oxygen and Water Vapor Dynamics in Modified-Atmosphere Packages. J. Food Sci. 61, 956-961.

Geysen, S., Verlinden, B.E., Conesa, A., Nicolai, B.M., 2005. Modelling respiration of strawberry (cv. Elsanta) as a function of temperature, carbon dioxide, low and superatmospheric oxygen concentration. Frutic 5, 12-16.

Gwanpua, S.G., Vicent, V., Verlinden, B.E., Hertog, M., Nicolai, B.M., Geeraerd, A.H., 2014. Managing biological variation in skin background colour along the postharvest chain of 'Jonagold' apples. Postharvest Biol. Technol. 93, 61-71.

Han, C., Zhao, Y., Leonard, S.W., Traber, M.G., 2004. Edible coatings to improve storability and enhance nutritional value of fresh and frozen strawberries (Fragariax ananassa) and raspberries (Rubus ideaus). Postharvest Biol. Technol. $33,67-78$.

Hertog, M., Boerrigter, H.A.M., Van den Boogaard, G., Tijskens, L.M.M., Van Schaik, A.C.R., 1999. Predicting keeping quality of strawberries (cv.Elsanta') packed under modified atmospheres: an integrated model approach. Postharvest Biol. Technol. 15, 1-12.

Hertog, M., Lammertyn, J., De Ketelaere, B., Scheerlinck, N., Nicolaï, B.M., 2007a. Managing quality variance in the postharvest food chain. Trends food Sci. Technol. 18, 320-332.

Hertog, M., Lammertyn, J., Desmet, M., Scheerlinck, N., Nicolaï, B.M., 2004. The impact of biological variation on postharvest behaviour of tomato fruit. Postharvest Biol. Technol. 34, 271-284.

Hertog, M., Scheerlinck, N., Lammertyn, J., Nicolaï, B.M., 2007b. The impact of biological variation on postharvest behaviour of Belgian endive: The case of multiple stochastic variables. Postharvest Biol. Technol. 43, 78-88. 
Hertog, M., Scheerlinck, N., Nicolaï, B.M., 2009a. Monte Carlo evaluation of biological variation: Random generation of correlated non-Gaussian model parameters. J. Comput. Appl. Math. 223, 1-14.

Hertog, M., Scheerlinck, N., Nicolaï, B.M., 2009b. Monte Carlo evaluation of biological variation: Random generation of correlated non-Gaussian model parameters. J. Comput. Appl. Math. 223, 1-14.

Jalali, A., Seiiedlou, S., Linke, M., Mahajan, P., 2017. A comprehensive simulation program for modified atmosphere and humidity packaging (MAHP) of fresh fruits and vegetables. J. Food Eng. 206, 88-97. https://doi.org/https://doi.org/10.1016/j.jfoodeng.2017.03.007

Joshi, K., Warby, J., Valverde, J., Tiwari, B., Cullen, P.J., Frias, J.M., 2018. Impact of cold chain and product variability on quality attributes of modified atmosphere packed mushrooms (Agaricus bisporus) throughout distribution. J. Food Eng. 232, $44-55$.

Kader, A.A., 1986. Biochemical and physiological basis for effects of controlled and modified atmospheres on fruits and vegetables. Food Technol.

Kader, A.A., 1984. Effects of postharvest handling procedures on tomato quality, in: Symposium on Tomato Production on Arid Land 190. pp. 209-222.

Kader, A.A., Saltveit, M.E., 2003. Respiration and gas exchange. Postharvest Physiol. Pathol. Veg. 2, 7-29.

Ke, D., Goldstein, L., O’MAHONY, M., Kader, A.A., 1991. Effects of Short-term Exposure to Low $\mathrm{O} 2$ and High $\mathrm{CO} 2$ Atmospheres on Quality Attributes of Strawberries. J. Food Sci. 56, 50-54.

Larsen, M., Watkins, C.B., 1995. Firmness and concentrations of acetaldehyde, ethyl acetate and ethanol in strawberries stored in controlled and modified atmospheres. 
Postharvest Biol. Technol. 5, 39-50.

Lee, D.S., Song, Y., Yam, K.L., 1996. Application of an enzyme kinetics based respiration model to permeable system experiment of fresh produce. J. Food Eng. 27, 297-310.

McNally, K., Cotton, R., Loizou, G.D., 2011. A Workflow for Global Sensitivity Analysis of PBPK Models. Front. Pharmacol. 2, 31. https://doi.org/10.3389/fphar.2011.00031

Merts, I., 1996. Mathematical Modelling of Modified Atmosphere Packaging Systems for Apples. Dep. Process Environ. Technol. Massey University, New Zealand.

Nunes, M.C.N., Brecht, J.K., Morais, A., Sargent, S.A., 1998. Controlling temperature and water loss to maintain ascorbic acid levels in strawberries during postharvest handling. J. Food Sci. 63, 1033-1036.

Pelayo, C., Ebeler, S.E., Kader, A.A., 2003. Postharvest life and flavor quality of three strawberry cultivars kept at $5 \mathrm{C}$ in air or air+ $20 \mathrm{kPa} \mathrm{CO}$ 2. Postharvest Biol. Technol. 27, 171-183.

Petriccione, M., Mastrobuoni, F., Pasquariello, M.S., Zampella, L., Nobis, E., Capriolo, G., Scortichini, M., 2015. Effect of chitosan coating on the postharvest quality and antioxidant enzyme system response of strawberry fruit during cold storage. Foods 4, 501-523.

R Development Core Team, 2008. R: A Language and Environment for Statistical Computing. https://doi.org/\{ISBN\} 3-900051-07-0

Rennie, T.J., Tavoularis, S., 2009. Perforation-mediated modified atmosphere packaging: Part I. Development of a mathematical model. Postharvest Biol. Technol. 51, 1-9. https://doi.org/http://dx.doi.org/10.1016/j.postharvbio.2008.06.007 
Sanz, C., Perez, A.G., Olias, R., Olias, J.M., 2000. Modified atmosphere packaging of strawberry fruit: Effect of package perforation on oxygen and carbon dioxide/Envasado de fresas en atmósfera modificada: Efecto de la perforación del envase en el contenido de oxígeno y dióxido de carbono. Food Sci. Technol. Int. 6, $33-38$.

Siracusa, V., 2012. Food packaging permeability behaviour: a report. Int. J. Polym. Sci. 2012.

Soetaert, K., Petzoldt, T., Setzer, R.W., 2010. Solving differential equations in R: package deSolve. J. Stat. Softw. 33, 1-25.

Song, Y., Vorsa, N., Yam, K.L., 2002. Modeling respiration-transpiration in a modified atmosphere packaging system containing blueberry. J. Food Eng. 53, 103-109. https://doi.org/http://dx.doi.org/10.1016/S0260-8774(01)00146-7

Tijskens, L.M.M., Polderdijk, J.J., 1996. A generic model for keeping quality of vegetable produce during storage and distribution. Agric. Syst. 51, 431-452.

Wickham, H., 2009. ggplot2: Elegant Graphics for Data Analysis. https://doi.org/978-0$387-98140-6$

Xanthopoulos, G., Koronaki, E.D., Boudouvis, A.G., 2012. Mass transport analysis in perforation-mediated modified atmosphere packaging of strawberries. J. Food Eng. 111, 326-335. https://doi.org/http://dx.doi.org/10.1016/j.jfoodeng.2012.02.016

Zagory, D., Kader, A.A., 1988. Modified atmosphere packaging of fresh produce. Food Technol. 42, 70-77.

Zhang, M., Xiao, G., Peng, J., Salokhe, V.M., 2003. Effects of modified atmosphere package on preservation of strawberries. Zool. Stud. 42, 143-148. 
Table 1 Equations used in the mathematical model

\begin{tabular}{|c|c|c|c|}
\hline Process & Equation & Reference & Eq. no. \\
\hline Respiration & $\begin{array}{l}r_{O_{2}}=\frac{V m_{O_{2}} \cdot\left[O_{2}\right]}{K m_{O_{2}} \cdot\left(1+\frac{\left[\mathrm{CO}_{2}\right]}{K m C_{C O} O_{2}}\right)+\left[O_{2}\right] \cdot\left(1+\frac{\left[\mathrm{CO}_{2}\right]}{K m u_{C O}}\right)} \\
r_{\mathrm{CO}_{2}(f)}=\frac{V m_{\mathrm{CO}_{2}(f)}}{\left(1+\frac{\left[O_{2}\right]}{K m c_{O_{2}(f)}}+\frac{\left[C \mathrm{CO}_{2}\right]}{K m c_{C O_{2}(f)}}\right) \cdot K m_{\mathrm{CO}_{2}(f)}+1} \\
r_{\mathrm{CO}_{2}}=R Q_{o x} \cdot r_{O_{2}}+r_{\mathrm{CO}_{2}(f)}\end{array}$ & $\begin{array}{l}\text { Strawberry respiration rate follow uncompetitive type } \\
\text { inhibition. The } \mathrm{CO}_{2} \text { production is a combination of oxidative } \\
\text { and the fermentative process (Hertog et al., 1999; Song et al., } \\
\text { 2002) }\end{array}$ & $\begin{array}{l}20 \\
21 \\
22\end{array}$ \\
\hline Respiration heat & $Q_{s}=\frac{2816}{6} \times \frac{r_{\mathrm{O}_{2}}+r_{\mathrm{CO}_{2}}}{2} \times \alpha \times W_{p}$ & $\begin{array}{l}\alpha \text { is conversion factor of respiration energy dissipated as heat. } \\
\text { The literature suggests the value of } \alpha \text { has a range between } 0.8- \\
1.0 \text { (Burton, 1982). For } 100 \% \text { conversion of respiration energy } \\
\text { as heat } \alpha=1 \text { (Song et al., 2002) }\end{array}$ & 23 \\
\hline \multicolumn{4}{|l|}{ Mass Balance } \\
\hline $\begin{array}{l}\text { Gas exchange in } \\
\text { package }\end{array}$ & $\begin{array}{l}\frac{d\left[\mathrm{O}_{2}\right]_{i}}{d t}=100 \times\left(\frac{A_{p} P_{O_{2}} P_{a t m}}{L_{f}}\left[\frac{\left[O_{2}\right]_{o}}{100}-\frac{\left[O_{2}\right]_{i}}{100}\right]-W_{p} r_{O_{2}}\right) \times \frac{1}{V_{f}} \\
\frac{d\left[\mathrm{CO}_{2}\right]_{i}}{d t}=100 \times\left(\frac{{ }_{p} P_{C_{2} P_{a t m}}}{L_{f}}\left[\frac{\left[\mathrm{CO}_{2}\right]_{o}}{100}-\frac{\left[\mathrm{CO}_{2}\right]_{i}}{100}\right]+W_{s} r_{\mathrm{CO}_{2}}\right) \times \frac{1}{V_{f}}\end{array}$ & $\begin{array}{l}\text { The mass balance of gas components in the package is } \\
\text { represented by ordinary differential equations (Song et al., } \\
\text { 2002). } \\
\text { As the package initially contains air, initial conditions }(\mathrm{t}=0 \text { ) } \\
\text { becomes }\left[\mathrm{O}_{2}\right]_{\mathrm{i}}=21.0 \%,\left[\mathrm{CO}_{2}\right]_{\mathrm{i}}=0.03 \%\end{array}$ & 24 \\
\hline Permeability & $P_{O_{2}, \mathrm{CO}_{2}, \mathrm{H}_{2} \mathrm{O}}=P_{\mathrm{O}_{2}, \mathrm{CO}_{2}, \mathrm{H}_{2} \mathrm{O} \text { ref }}+\frac{\pi R_{h}^{2} \times D_{i, a i r}}{\left(L_{f}+R_{h}\right)} \times N_{h}$ & $\begin{array}{l}\text { Permeability is a function of permeability of film and the } \\
\text { number and size of perforations. }\end{array}$ & 26 \\
\hline
\end{tabular}




\begin{tabular}{|c|c|c|c|}
\hline $\begin{array}{l}\text { Water permeation } \\
\text { through film }\end{array}$ & $\frac{d m_{p r}}{d t}=\left[\frac{P_{H_{2} O} A_{p}\left(P_{i}-P_{o}\right)}{L_{f}}\right]\left[\frac{0.018 P_{a t m}}{R T_{s}}\right]$ & $\begin{array}{l}\text { The driving force of permeation of water vapour from the } \\
\text { headspace of package to surrounding is the water vapour } \\
\text { pressure difference. }\end{array}$ & 27 \\
\hline \multicolumn{4}{|l|}{ Heat Balance } \\
\hline $\begin{array}{l}\text { Temperature } \\
\text { headspace of } \\
\text { package }\end{array}$ & $\begin{array}{r}Q_{s} W_{s}+Q_{c o n}+h_{p} A_{p}\left(T_{i}-T_{o}\right) \\
=Q_{t r}+W_{s} C_{s} \frac{d T_{s}}{d t}+W_{a} C_{a} \frac{d T_{s}}{d t} \\
\frac{d T_{s}}{d t}=\frac{Q_{r}+Q_{c o n}-h_{p} A_{p}\left(T_{i}-T_{o}\right)-Q_{t r}}{W_{s} C_{s}+W_{a} C_{a}}\end{array}$ & $\begin{array}{l}\text { The heat is generated by respiration and heat is transferred in } \\
\text { headspace due to convection, transpiration and condensation. } \\
\text { This ODE is used to estimate the temperature of the fresh } \\
\text { produce (Lee et al., 1996) }\end{array}$ & 29 \\
\hline
\end{tabular}


Table 2 Parameter estimate and their standard error for strawberry Source:

(*Becker et al., 1996; Hertog et al., 1999)

\begin{tabular}{|c|c|c|}
\hline Parameter & Value & Standard error (SE) \\
\hline$V m_{O_{2}, \text { ref }}\left(\mu \mathrm{mol} \mathrm{kg}{ }^{-1} \mathrm{sec}^{-1}\right)$ & 0.27 & 0.010 \\
\hline$E_{a V m_{O_{2}}}\left(\mathrm{~J} \mathrm{~mol}^{-1}\right)$ & 74826 & 3451 \\
\hline$V m_{\mathrm{CO}_{2}(f) r e f}\left(\mu \mathrm{mol} \mathrm{kg}{ }^{-1} \mathrm{sec}^{-1}\right)$ & 0.50 & 0.22 \\
\hline$E_{a_{V m_{C O}(f)}\left(\mathrm{J} \mathrm{mol}^{-1}\right)}$ & 57374 & 14400 \\
\hline$K m_{\mathrm{O}_{2}}(\%)$ & 2.63 & 0.274 \\
\hline $\mathrm{Kmc}_{\mathrm{CO}_{2}}$ & $+\infty$ & - \\
\hline $\mathrm{Kmu}_{\mathrm{CO}_{2}}$ & $+\infty$ & - \\
\hline$K m c_{O_{2}(f)}(\%)$ & 0.056 & 0.041 \\
\hline $\mathrm{Kmc}_{\mathrm{CO}_{2}(f)}$ & $+\infty$ & - \\
\hline $\mathrm{Km}_{\mathrm{CO}_{2}(f)}(\%)$ & 1 & - \\
\hline $\mathrm{K}_{\mathrm{s}}{ }^{*}\left(\mathrm{~kg} \mathrm{~m}^{-2} \mathrm{sec} \mathrm{Pa}\right)$ & $13.6 \times 10^{-9}$ & 4.8 \\
\hline$k_{s, \text { ref }}\left(\right.$ day $\left.^{-1}\right)$ & 0.60 & 0.045 \\
\hline$E a_{s}\left(\mathrm{~J} \mathrm{~mol}^{-1}\right)$ & 70108 & 7056 \\
\hline $\mathrm{N}_{0}(\%)$ & 0.83 & 0.10 \\
\hline
\end{tabular}

Table 3 Properties of packaging film, produce and other conditions used in the model

\begin{tabular}{|l|l|l|}
\hline$P_{O_{2} \text { ref }}\left(\mathrm{m}^{3} \mathrm{~m} \mathrm{~h}^{-1} \mathrm{~m}^{-2} \mathrm{~Pa}\right)$ & $8.5 \times 10^{-14}$ & (Xanthopoulos et al., 2012) \\
\hline$P_{C O_{2} r e f}\left(\mathrm{~m}^{3} \mathrm{~m} \mathrm{~h}^{-1} \mathrm{~m}^{-2} \mathrm{~Pa}\right)$ & $2.8 \times 10^{-13}$ & (Xanthopoulos et al., 2012) \\
\hline$P_{\mathrm{H}_{2} O \text { Oref }}\left(\mathrm{m}^{3} \mathrm{~m} \mathrm{~h}^{-1} \mathrm{~m}^{-2} \mathrm{~Pa}\right)$ & $4.5 \times 10^{-13}$ & (Xanthopoulos et al., 2012) \\
\hline$\rho_{b}\left(\mathrm{~kg} \mathrm{~m}^{-3}\right)$ & 600 & (Xanthopoulos et al., 2012) \\
\hline$\epsilon$ & 0.27 & (Xanthopoulos et al., 2012) \\
\hline$a_{w}$ & 0.99 & (Xanthopoulos et al., 2012) \\
\hline$C_{S}\left(\mathrm{~kJ} \mathrm{~kg}^{-1} \mathrm{~K}^{-1}\right)$ & 4 & (ASHRAE, 2006) \\
\hline$\left[C O_{2}\right]_{i}(\%)$ & 0.03 & (Song et al., 2002) \\
\hline$\left[O_{2}\right]_{i}(\%)$ & 21.0 & (Song et al., 2002) \\
\hline$M_{O_{2}}\left(\mathrm{~kg} \mathrm{~mol}^{-1}\right)$ & 0.032 & (Bird, 2002) \\
\hline$M_{C O_{2}}\left(\mathrm{~kg} \mathrm{~mol}^{-1}\right)$ & 0.044 & (Bird, 2002) \\
\hline$M_{\mathrm{H}_{2} O}\left(\mathrm{~kg} \mathrm{~mol}^{-1}\right)$ & 0.018 & (Bird, 2002) \\
\hline$R\left(\mathrm{~J} \mathrm{~K} \mathrm{~K}^{-1} \mathrm{~mol}^{-1}\right)$ & 8.314 & (Bird, 2002) \\
\hline$P_{a t m}(\mathrm{~Pa})$ & 101325 & (Bird, 2002) \\
\hline$\rho_{O_{2}}\left(\mathrm{~kg} \mathrm{~m}^{-3}\right)$ & 1.43 & (Siracusa, 2012) \\
\hline
\end{tabular}




\begin{tabular}{|l|l|l|}
\hline$\rho_{\mathrm{CO}_{2}}\left(\mathrm{~kg} \mathrm{~m}^{-3}\right)$ & 1.98 & (Siracusa, 2012) \\
\hline$T_{r e f}\left({ }^{0} \mathrm{C}\right)$ & 10 & (Hertog et al., 1999) \\
\hline$N_{H}$ & 4 & Experimental \\
\hline$d_{c}(\mathrm{~m})$ & 0.03 & Experimental \\
\hline
\end{tabular}

\section{List of Figures}

Fig 1. Simulation results of average (a) oxygen concentration and (b) carbon dioxide concentration in the headspace of packages (c) weight loss observed and (d) spoilage against the cold chain profile.

Fig 2 Propagation of product parameter variability observed in (a) concentration of oxygen (b) carbon dioxide in headspace (c) weight loss and (d) Spoilage observed in strawberry packed in modified atmosphere 15 days storage at $4^{0} \mathrm{C}$ and $80 \%$ RH.

Fig 3 The effect of cold chain uncertainty (green) and product parameter uncertainty (orange) on the (a) oxygen concentration (b) carbon dioxide concentration in headspace (c) weight loss during storage (d) Spoilage of strawberry. Each subplot within (a), (b), (c) and (d) represents the simulated variation in a given distribution day

Fig. 4 Lowry plot for the effect of product parameters on the a) weight loss b) spoilage, c) $\mathrm{CO} 2$

Fig. 5 Comparison of model predictions with the experimental data (points) at different storage conditions $((4,8,200 \mathrm{C})(\mathrm{a}, \mathrm{b})$ and at ideal temperature (40C) (c,d) a) weight loss b) spoilage at $(4,8,200 \mathrm{C})$, c) weight loss and d) spoilage at (40C).

Fig. 6 Conditional density plot of total waste generated in the strawberry supply chain. 

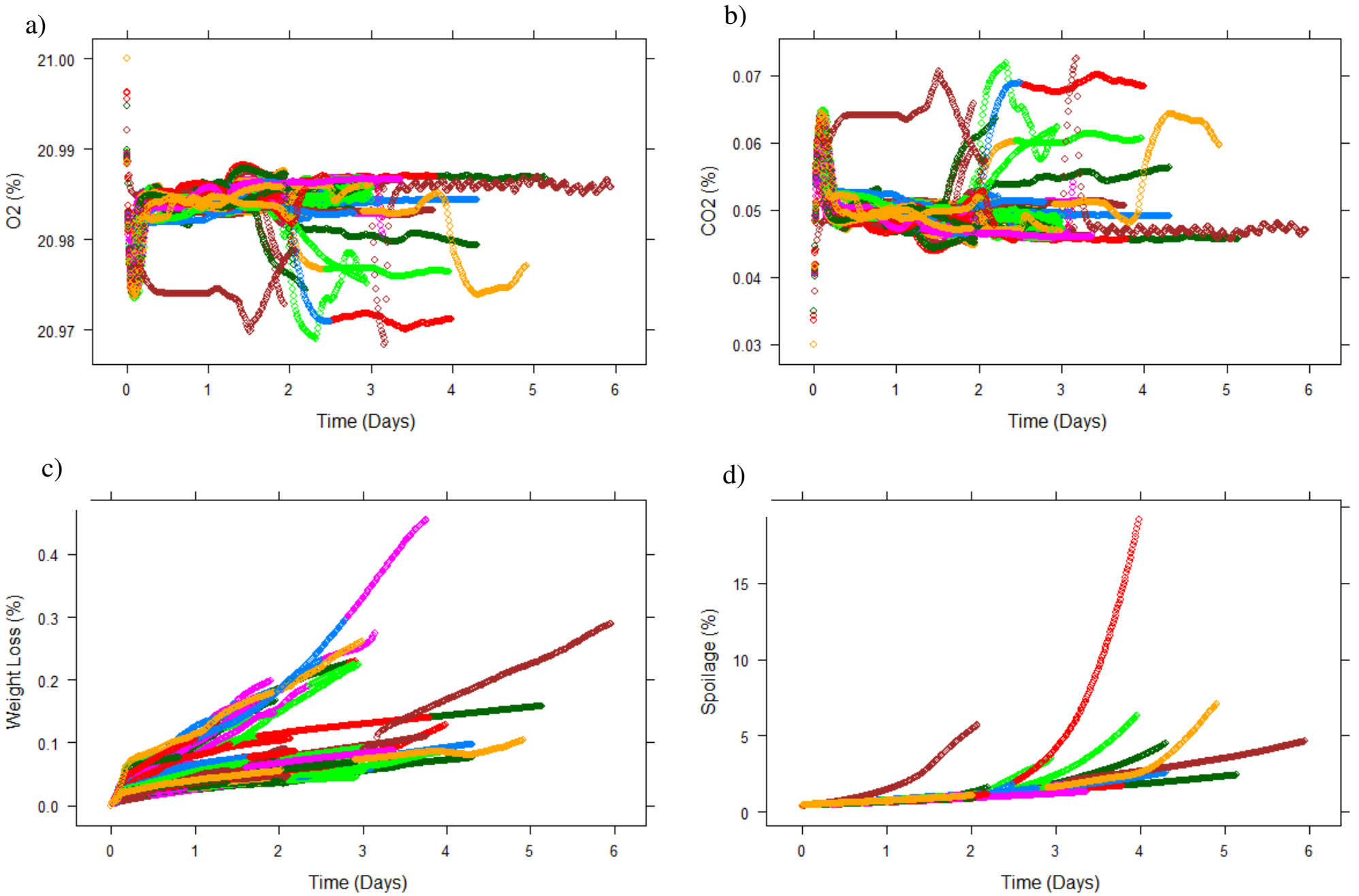

Fig 1. Simulation results of average (a) oxygen concentration and (b) carbon dioxide concentration in the headspace of packages (c) weight loss observed and (d) spoilage against the cold chain profile. 

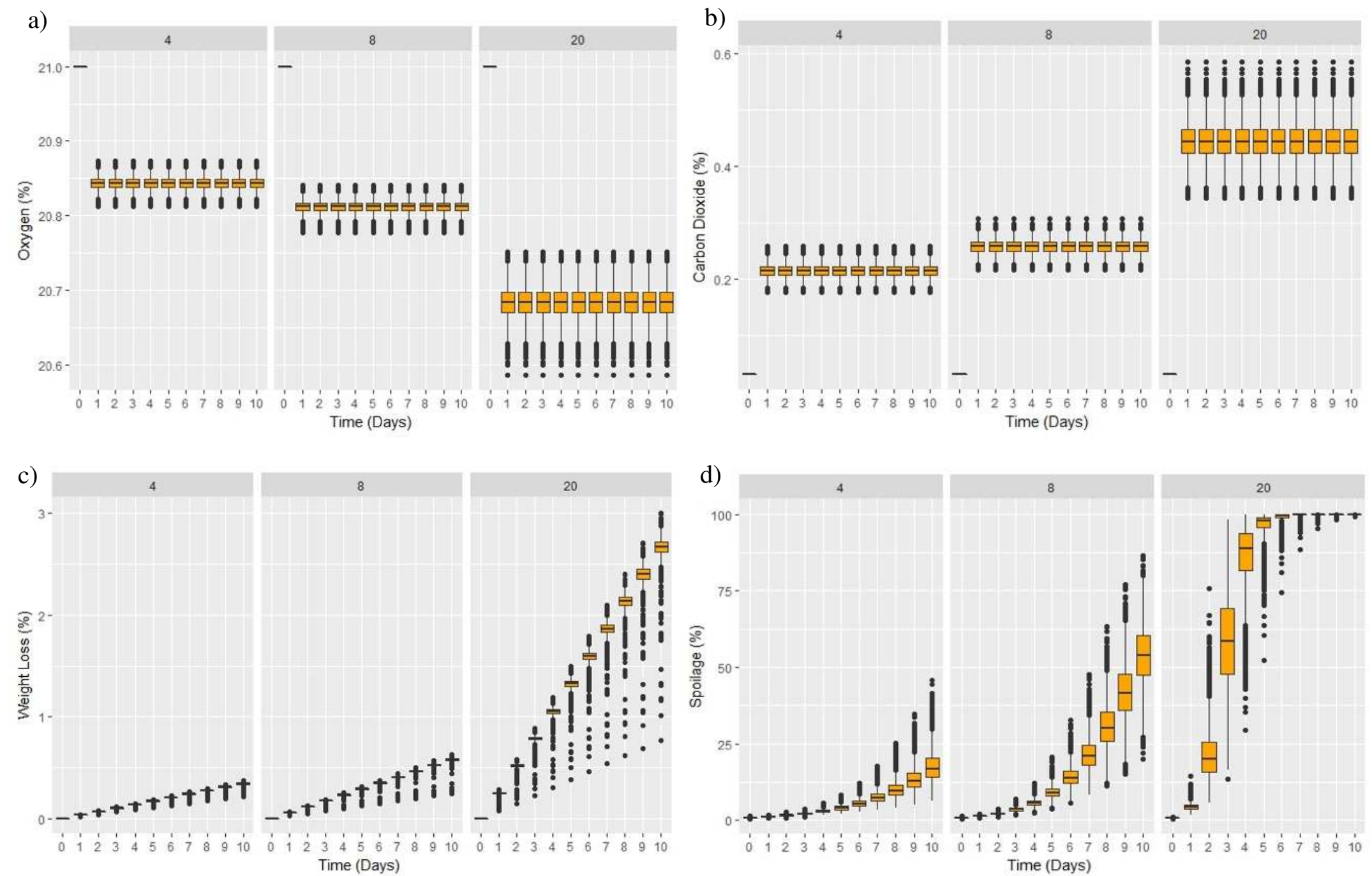

Fig 2 Propagation of product parameter variability observed in (a) concentration of oxygen (b) carbon dioxide in headspace (c) weight loss and (d) Spoilage observed in strawberry packed in modified atmosphere 15 days storage at $4^{0} \mathrm{C}$ and $80 \% \mathrm{RH}$ with subplots showing 4, 8 and 20 perforations in the package . 
a)

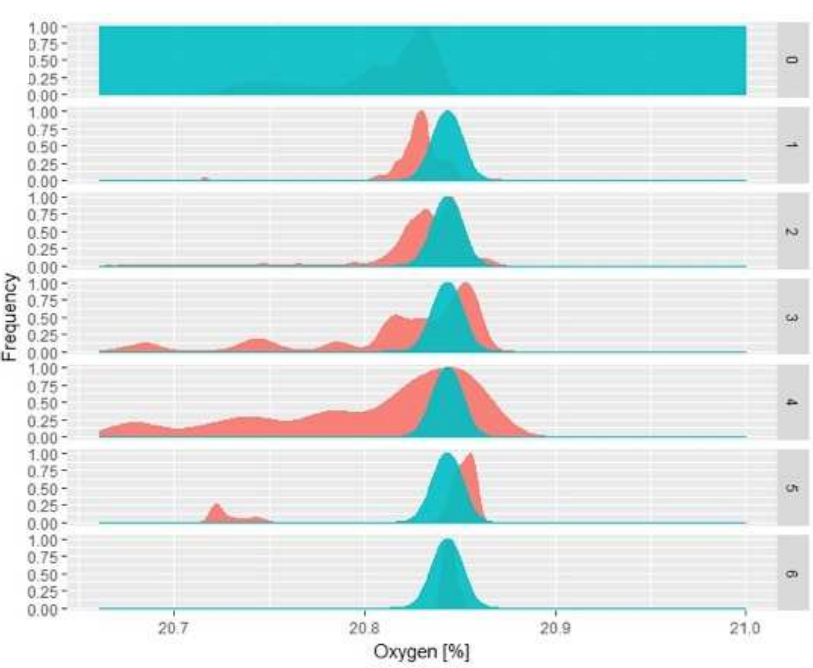

c)

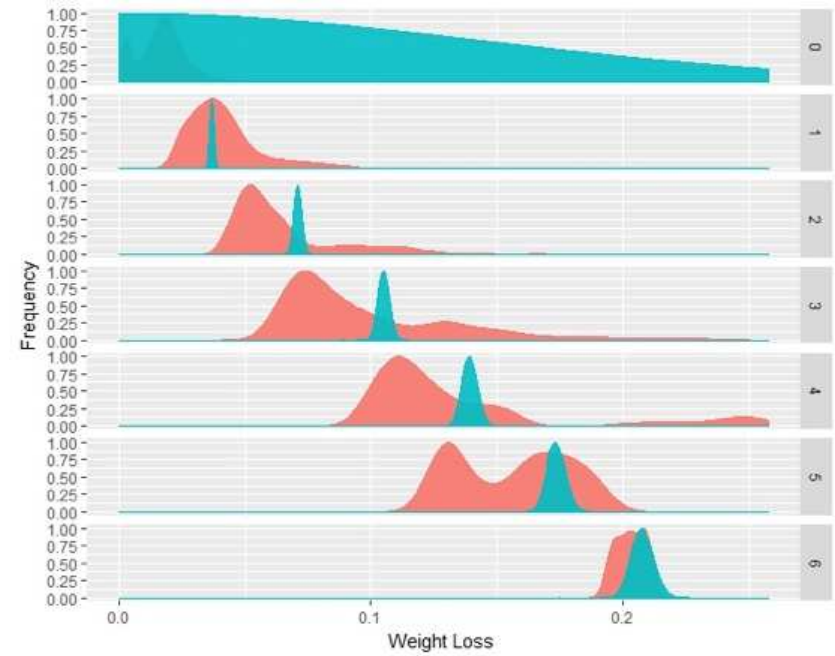

b)
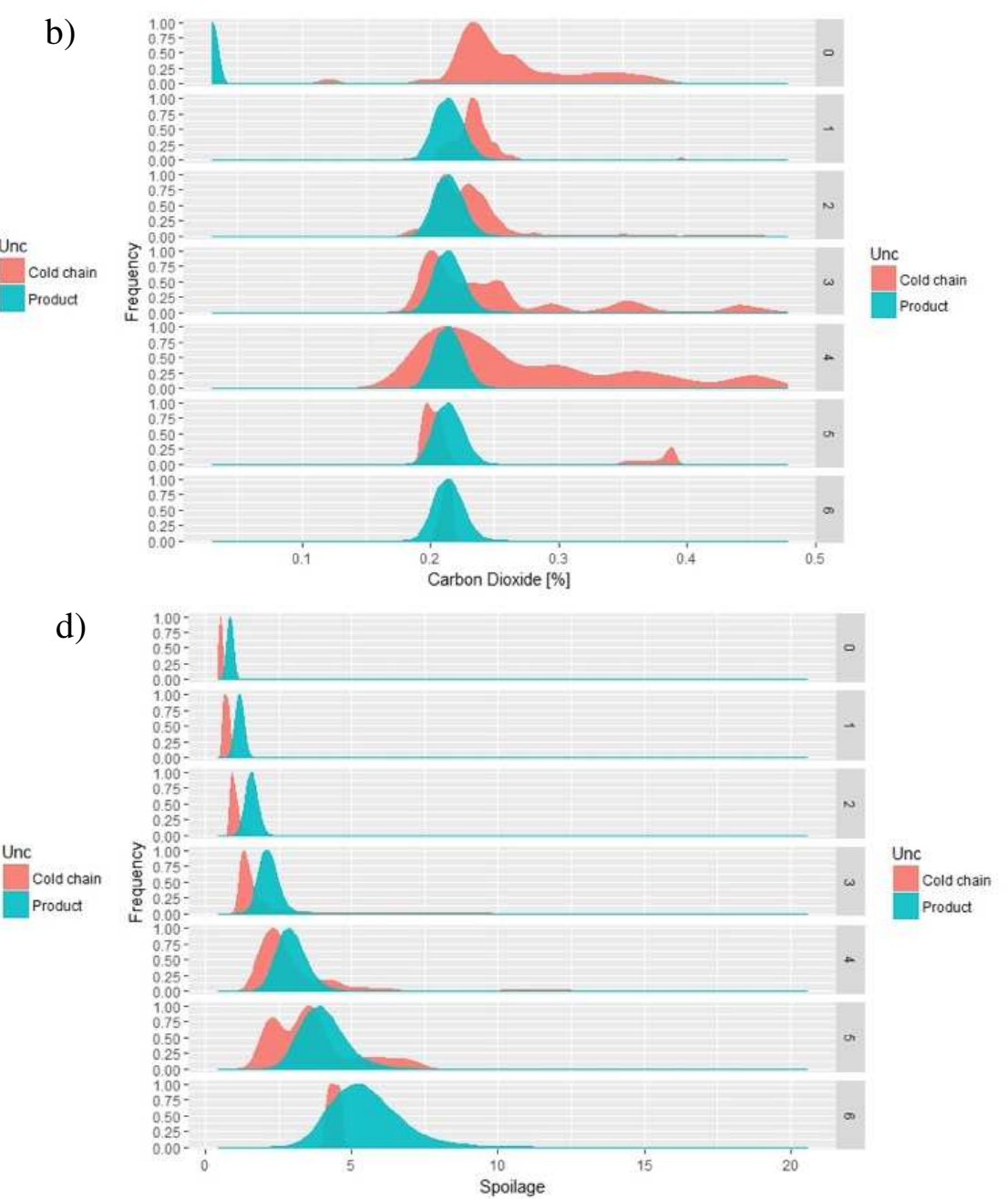

Fig 3 The effect of cold chain uncertainty (green) and product parameter uncertainty (orange) on the (a) oxygen concentration

(b) carbon dioxide concentration in headspace (c) weight loss during storage (d) Spoilage of strawberry. Each subplot within

(a), (b), (c) and (d) represents the simulated variation in a given distribution day 
a)

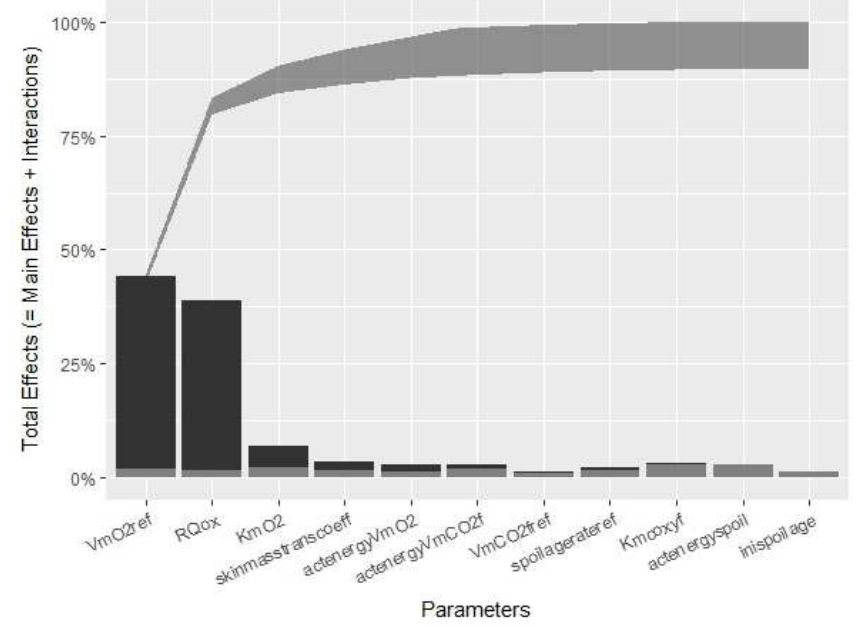

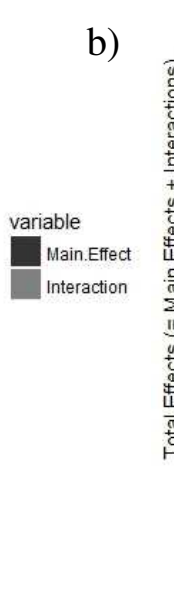

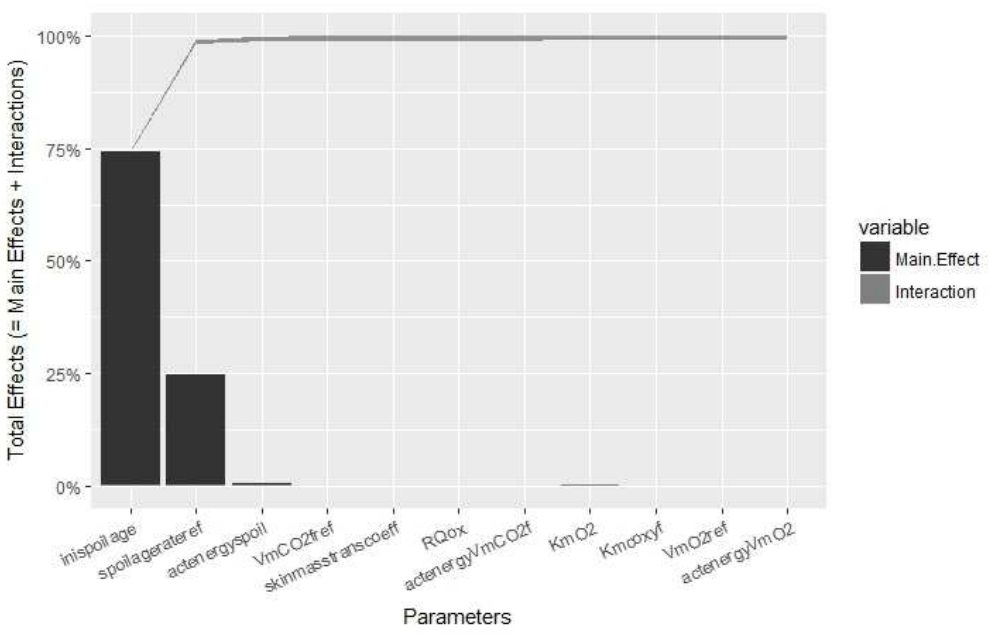

c)

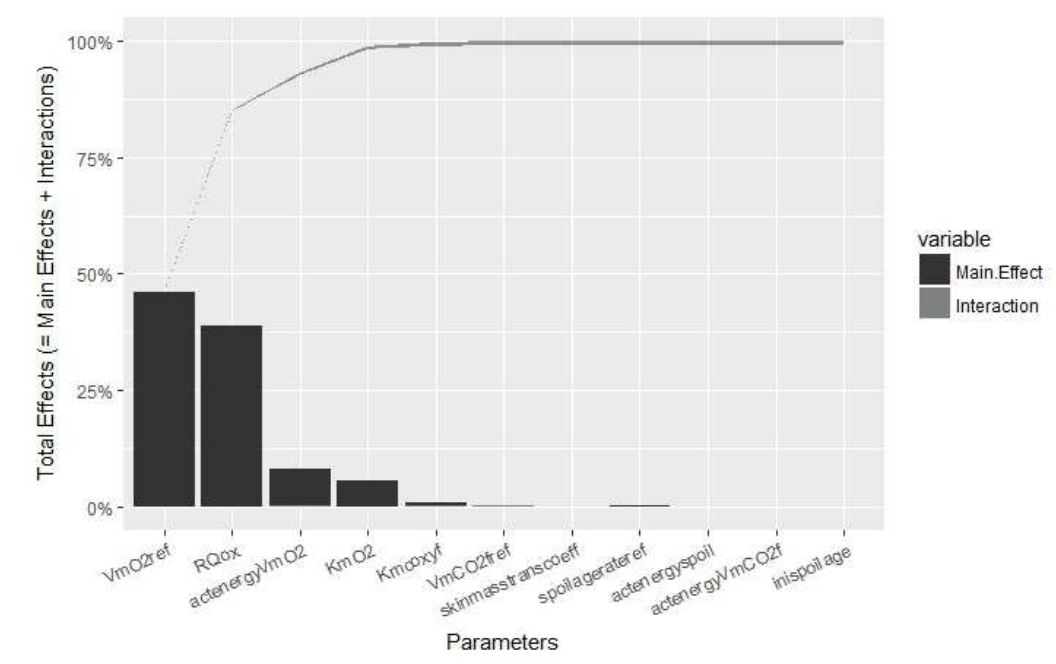

Fig. 4 Lowry plot for the effect of product parameters on the a) weight loss b) spoilage, c) $\mathrm{CO}_{2}$ 

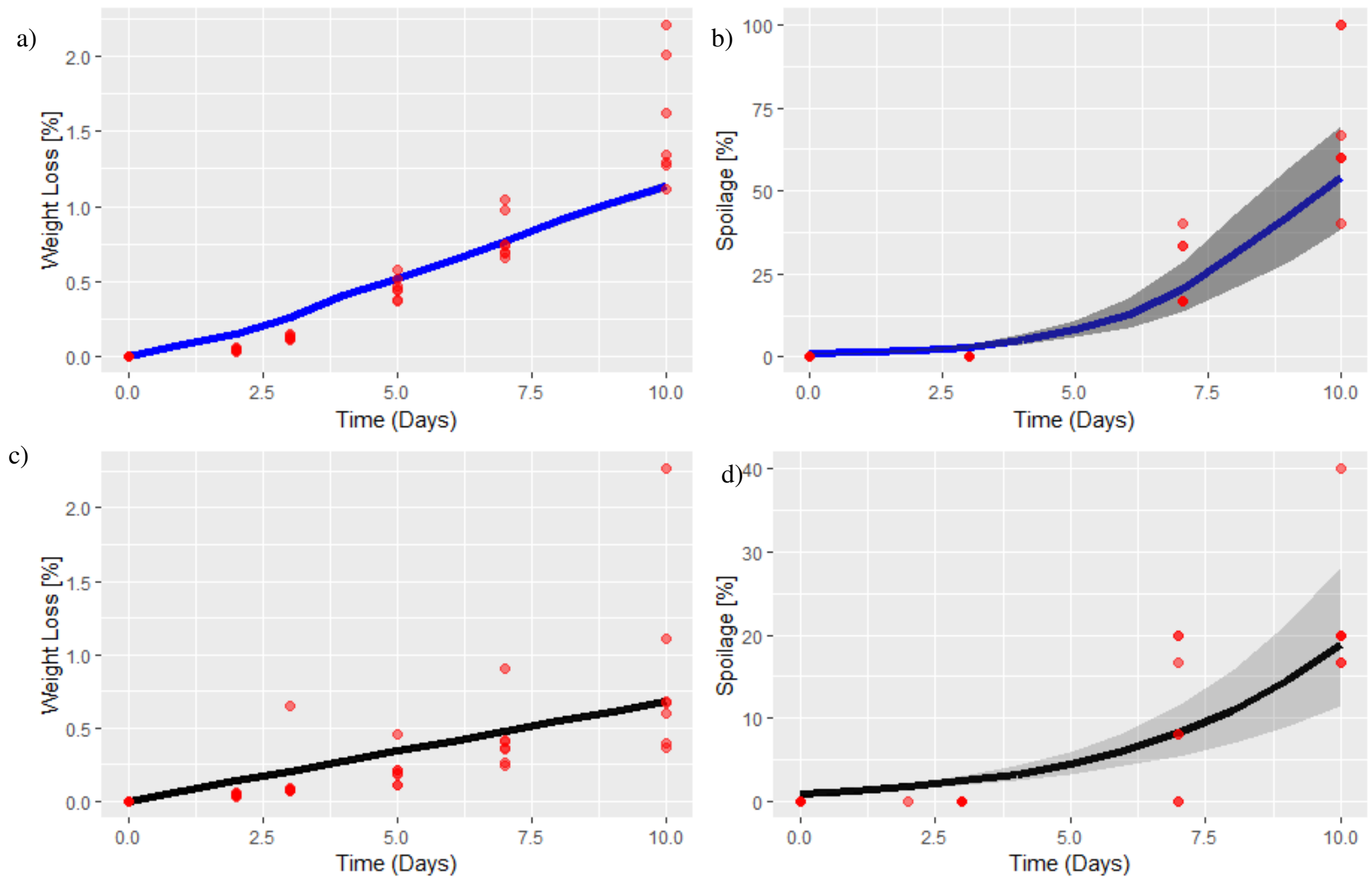

Fig 5 Comparison of model predictions with the experimental data (points) at abusive (a, b) and ideal storage conditions (c,d) a) weight loss b) spoilage at abusive, c) weight loss and d) spoilage at ideal for uncoated strawberries. 


\section{No Coating}

a)

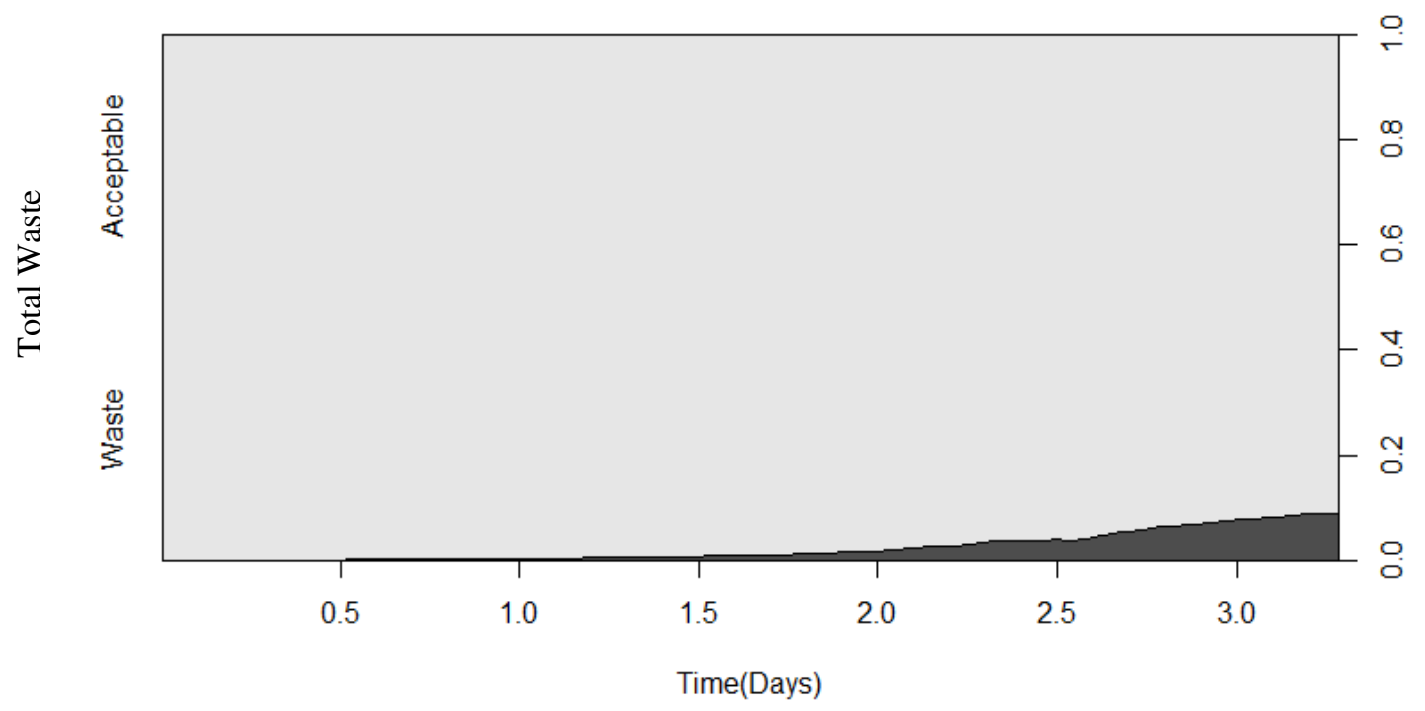

\section{Coating}

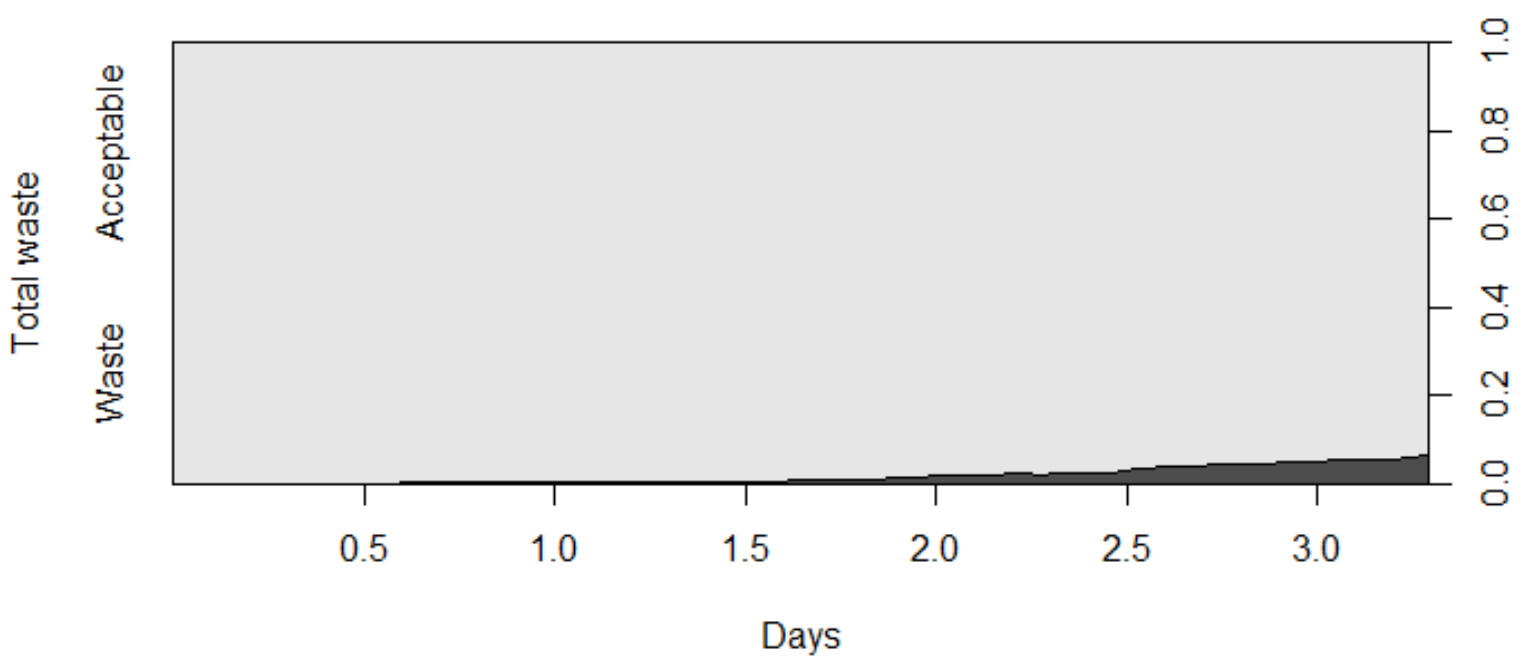

Fig Error! No text of specified style in document.. Conditional density plot for the estimation of total waste generated in a) uncoated and b) coated strawberries. 